Tom Priestly

University of Alberta

\title{
On Derivational Productivity in Slovene with Notes on Lexical Frequency and Awareness of the Norm
}

\begin{abstract}
Raziskana sta dva izpridevniška glagolska besedotvorna vzorca: »inhoativno« obrazilo -eti in "faktitivno« obrazilo -iti. Poglavitni cilj raziskave je ugotavljanje možnosti za merjenje produktivnosti besedotvornih vzorcev. Analiza je bila izpeljana na osnovi psihološkega testiranja, izvedenega v Ljubljani v letih 1993-94. Glede produktivnosti je avtor prišel do treh zaključkov: prvič, produktivnost se da opisati kot poševni potek, vendar v dveh različnih pomenih izraza; drugič, obstaja velika razlika med vrstno pogostnostjo in produktivnostjo; tretjič, posebna formula omogoča merjenje relativne produktivnosti različnih vzorcev, in sicer je obrazilo -iti po pričakovanju bolj produktivno kot -eti. Testiran je bil tudi pojav »blokiranja«, vendar brez dokončnih rezultatov. Avtor je prišel tudi do dveh stranskih zaključkov: nekateri kvalifikatorji za glagole v SSKJ se zdijo glede na rezultate raziskave nepravilni in jih bo treba ponovno oceniti in po možnosti tudi empirično utemeljiti; možno je določiti, kateri govorci slovenščine se najbolj zavedajo norme. Ti rezultati imajo pomen za šolske učitelje slovenščine.

Two deadjectival verbal derivative patterns - the "inchoative" -eti and the "factitive" -iti were investigated. The major aim was to discover a way of measuring the productivity of derivative patterns; the method involved psycholinguistic tests, adminstered in four schools and four university departments in Ljubljana in 1993-94. With regard to productivity, there are three conclusions. First, it is clear that, at least for these derivative patterns, productivity is a "cline," but in two distinct meanings of the term. Second, there is an enormous difference between type frequency and productivity. Third, one particular formula appears to provide a measure of the relative productivity of different patterns, and specifically shows that - as hypothesized - -iti is more productive than -eti. A test of the phenomenon known as blocking was also adminstered, with inconclusive results. Incidentally, two other conclusions were reached. Several of the stylistic labels (kvalifikatorji) in the SSKJ that are provided for verbs used in the tests appear, on this evidence, to be incorrect; this finding may only apply to to subjects in the tests, who were mostly aged between 16 and 24; but it is suggested that the kvalifikatorji deserve re-examination and, if possible, empirical justification. Also, it is shown that it is possible to determine which speakers of Slovene have a greater, and which ones have a lesser, awareness of the standard norm; this has implications for teachers of the Slovene language in schools.
\end{abstract}

\section{Introduction}

In his Slovenska slovnica Toporišič (1984: 123) writes that "besedotvorne vrste in sredstva niso vsi enako živi in pogostni." There are two different, if interconnected, phenomena involved here: productivity and frequency. The relevance of the latter is discussed below. First, let us define derivational productivity, using the words of Schultinck (1961, see Lieber 1992): "The possibility for language users to coin, unintentionally, a number of formations which are in principle uncountable." It is true that Slovene-speakers can freely coin many new derivations; and it is also true, as Toporišič points out, that there is variation in the productivity of derivation- 
al processes or patterns in a language like Slovene. Unfortunately, little has been done to analyze, or even tentatively explore, the dimensions of this variation in Slovene; most recent advances in the study of productivity have been based on evidence from Dutch, English and French (see, respectively, Baayen 1992, Lieber 1992, Corbin 1987). Descriptions of Slovene derivation written for Slovenes, such as the section "Besedotvorje" from which the above citation comes (Toporišič 1984: 109-174), are generally uninformative about productivity, and what is imparted is usually only implicit: if one derivation is exemplified with more words than a second, the reader may infer that the first is more productive. In, e.g., the section "Izpeljava pridevnikov iz predložnih zvez," we find examples of four adjectives with brez- and only one with $v z-$; this ratio presumably reflects the lesser productivity of derivations incorporating the second prefix. But this lack of explicit information hardly matters, inasmuch as the productivity of the different components is obvious to native speakers. In specialized studies of Slovene derivation there is a similar dearth of information on productivity: such studies have generally concentrated either on the semantic mechanisms involved (thus, many analyses by Vidovič-Muha, e.g., 1981, 1983), or single derivative affixes (e.g., Gjurin 1985); remarks about comparative productivity have not been appropriate to studies such as these (see Priestly 1987: 195). ${ }^{1}$ I undertook a preliminary investigation of productivity in Slovene derivation in the early 1990 s to begin to remedy this lack of information. ${ }^{2}$ Two derivational processes or patterns [henceforward, $\mathrm{DPs}^{3}$ ] were selected for the investigation: the verbalizing affixes $-e$ - and $-i-$, when suffixed to adjectival stems and denoting inchoativity and factitivity respectively, e.g.: rjav 'brown', rjaveti 'to become brown', rjaviti 'to make [someone or something] brown.' A glance at any dictionary of Slovene will show that factitive derivations from adjectives outnumber inchoative ones; the hypothesis

\footnotetext{
${ }^{1}$ Occasionally, as in Vidovič-Muha (1983: 371), productivity is mentioned: "Skladenjske, obrazilne, naglasne pa tudi predmetnopomenske lastnosti obravnavanih zloženk so torej takšne, da nam omogočajo natančno določitev obsega njihove tvornosti." This is however an opportunity of precisely specifying the 'scope of creativity' not of any one particular process, but rather of the components of its 'speech base' (govorna podstava). Moreover, it is the relative frequency of the base components that is provided, which may not be the same as their productivity, see below.

${ }^{2}$ I express my thanks, above all, for funding this research, to the Social Sciences and Humanities Research Council of Canada; and also to the following: for his untiring practical assistance, to Zoran Starčević; for their advice, to Ada Vidovič-Muha and Velemir Gjurin; for their interventions, to Minister Slavko Gaber and other personnel in the Ministrstvo za solstvo in šport; for their graciously allowing me into their schools and classes, to principals Srečko Božnar, Janja Kamnikar, Mirjena Kovač and Miha Šengalaja and the many teachers in their schools, and to university colleagues Miran Hladnik, Milica Kač, Stanko Klinar, Cveto Klofutar, Aleš Krbavčič, and France Žagar; and to the hundreds of students who participated in the tests, the vast majority of whom did so good-humouredly and conscientiously. The students were at the following high schools: Srednja šola za gostinstvo in turizem; Srednja šola za farmacijo in zdravstvo; Srednja upravno administrativna šola; and Gimnazija Moste, and in classes in the following departments and faculties of Ljubljana University: the Oddelek za germanske jezike Filozofske fakultete; Oddelek za farmacijo Fakultete za naravoslovje in tehnologijo; Biotehniška fakulteta; and the Pedagoška akademija.

${ }^{3}$ No assumption is made here in favour of or contrary to treating derivation as a process, or as a pattern, or as both; thus Schultinck's definition, which refers to "ability to coin new words," can be interpreted as involving mentally-stored processes, or as relying on psychological capacities to draw analogies from mentally-stored patterns, or as utilizing both. All my comments, descriptions and conclusions will, I suggest, be relevant for all three kinds of theoretical stance.
} 
to be tested was that this preponderance reflects a relative difference in productivity - a possibility that may or may not be true, given the unreliability of dictionary evidence.

The first decision was to not rely purely on data available in dictionaries. These data may appear useful, but discussions in the literature have emphasized how unreliable dictionary data are in this context. There are many reasons for this unreliability; especially, (1) dictionaries vary, and what is included in and excluded from them often depends on previous lexicographic work and/or the preferences of the compilers; (2) dictionaries usually fail to list every word written in the language, but even if (like the Oxford English Dictionary) they approach this ideal, they can never list every "actually existing" word in the spoken language, however this is normally defined; and (3) - most important in this context, see 3.2 - although type frequency can (laboriously) be extracted from them, dictionaries normally omit information about the relative token frequency of words. ${ }^{4}$ Additionally, (4) the relevance of possible but non-occurrent words for a study of productivity is difficult to deny, yet, obviously, no such words appear in dictionaries (see Corbin 1987: 18, Bauer 1988: 62-63, Baayen 1991).

It was therefore decided to investigate productivity by means of psycholinguistic testing: for if, following Schultinck, by this term we mean the ability of speakers to unintentionally create new lexemes, a study of Slovene productivity requires attempts to investigate the thought processes of speakers of Slovene. There were few models upon which such research could be based, ${ }^{5}$ and apparently none using Slavic linguistic material; hence, the choice of DPs was in part arbitrary, ${ }^{6}$ the selection of cues and of psycholinguistic testing procedures was cautious, and the methodology was developed in the field. The results presented below thus derive from a first foray into a little-developed subject-area, and should be considered tentative.

${ }^{4}$ Type frequency is the number of different lexemes in which a given item occurs; token frequency is the frequency with which that item occurs in a corpus. So, e.g., there being 64 words with the adverbial suffix -omal-ema listed among the approx. 40,000 words in Mader (1981), we may say that this suffix has a type frequency 0.16 . An analysis of the frequency of occurrence of all of these 64 words in a corpus of Modern Slovene may be expected to yield a higher percentage, given the frequency with which the word oziroma is used.

${ }^{5}$ The most suggestive study was Aronoff and Schvaneveldt (1978); these authors' technique which involved the three questions, "Is this item in your vocabulary?", "Is the item an English word?" and "Is the item a meaningful word?" - was used as a basis for the methodology chosen here, but one serious shortcoming in their experiment was not copied, namely, the fact that they did not use the same cues for the different components of the experiment, with the result that the results for these different components could not be meaningfully contrasted. Another example, but using only one question, is Anshen and Aronoff (1981). Greenberg and Quirk (1970) emphasize the informativeness of these three questions, cf. section 3.3 below. Psycholinguistic testing has been uncommon in Slavic linguistics generally; the only example known to me, which relies on grammaticality judgments, is Vakareliyska (1994). Asking subjects for assessments of potential (i.e., semantically plausible) words is just one of a large number of ways of investigating productivity; another, e.g., is asking for judgments of what are clearly nonsense words, see Derwing (1976).

${ }^{6}$ See further in 2.1. The choice was not arbitrary in that the inchoative and factitive deadival derivations form a contrasting pair; it was arbitrary in that I could easily have chosen another (contrasting or non-contrasting) pair of derivational processes/patterns. 


\section{Cues and Tests}

We administered an extensive battery of psycholinguistic tests over several weeks in Ljubljana in 1993. One result was very suggestive (see 3.3) and I returned to Ljubljana for a limited follow-up test in 1994.

\subsection{Cues}

Words to be used as cues were taken from the SSKJ: 27 randomly-selected verbs in -eti and 27 in -iti, all being semantically inchoative and factitive, respectively, and having an adjectival base (in most instances the semantic relationship between adjective and verb was transparent, see 5.1) To each list of "real" verbs six made-up verbs were added - verbs which could be derived from real Slovene adjectives, but which were not glossed in the SSKJ (see however 3.2). The complete lists are set out in Appendix I.

Given the importance of token frequency (see 3.2), it was judged desirable to select verbs that could be categorized in two groups - those occuring with greater and lesser token frequency as normally used by Slovene-speakers. Since no frequency dictionary of the language is yet available, the only clues of token frequency to be found in the SSKJ - indications of individual words' range of utilization - were used; viz., the kvalifikatorji or stylistic tags, here referred to as indicators, which are abbreviated and defined in the SSKJ as follows: knjiž.: "beseda, ki se rabi zlasti v leposlovnem ali znanstvenem jeziku"; raba peša: "beseda, ki se umika iz (splošne) rabe"; redko: "beseda, ki je sicer v splošni rabi, pa je v razmerju do sinonima precej redka"; star.: "beseda, ki je bila nekoč (v kaki funkciji) splošno rabljena; danes ima arhaično patino"; and zastar.: "nekoč rabljena beseda; danes je v knjižnem jeziku mrtva." One problem was posed by dictionary entries with multiple definitions, some with and some without an indicator. As a solution, the procedure adopted was as follows: if the first definition in the lemma for a given verb was furnished with one of these indicators, the verb was considered less frequently-occurring than one with no such indicator in its first definition. The inclusion of $\mathbf{k n j i z ̌}$. as an indicator of infrequent use also requires comment, for a word may be used only in literary/scientific styles but yet occur frequently therein; it was considered, however, that mere restriction to this stylistic function indicates that a word is not normally used in other functions, and is thus relatively rare. It might have been possible to rank-order the different indicators - thus, zastar. clearly is meant to indicate extremely low frequency - but the experiment design precluded including enough examples for such details to be comparable.

Here the presentation must be interrupted briefly to discuss what may be considered a potentially awkward procedural step, namely, reliance upon a comparison of two different DPs. At first glance it may appear that such a comparison is invalid, because the two DPs produce verbs with obviously different kinds of meaning. However, most of the meanings of the two kinds of Slovene verbs involved in these experiments differ minimally: e.g., 'to become brown' and 'to make [someone or something] brown' only differ in that the first is intransitive and the second transitive: in other respects, they both express a change of state from non-brownness to brownness. It is therefore assumed that comparisons of results for the two different 
DPs are, generally speaking, valid. Nevertheless, it is still possible that the comparisons made below are specifically invalid, because such tests depend, for their accuracy, on the sample of words being representative of the whole set. As one example, it could have happened - all the SSKJ indicators to the contrary - that, in my selection of actually-existing verbs, I picked 27 -iti verbs which are very common, and 27 -eti verbs which are very rare. To guard against this as far as possible, I made a random selection of verbs, within two clearly-defined groups - those with no indicators in the SSKJ, and those with the specific indicators listed above. For the 1994 tests the two sets of cues, each numbering 30 , comprised verbs similar to those used in 1993, but many more "made-up" words were substituted for "real" words, with the result that 16 "made-up" -eti and 14 "made-up" -iti words were included in the two sets of cues; they are listed in Appendix II.

\subsection{Tests}

The tests whose results are described here consisted of four questions: ${ }^{7}$

(1) Ali se po vašem beseda nahaja v knjižni slovenščini?

(2) Ali vi to besedo kdaj uporabljate?

(3) Ali je ta beseda po vašem možna in razumljiva?

(4) Kako pogosto sami uporabljate to besedo?

For brevity, these are referred to in the text and on the tables with the following labels: (1) "Standard?", (2) "Use?", (3) "Possibility?" and (4) "Frequency?". In all the tests described here, subjects selected and indicated a response on a five-point Likert scale. For questions (1), (2), and (3) the scale was "da/lahko/ne vem/menda ne/sploh ne"; for question (4) the scale was "zelo pogosto/pogosto/povprečno/redko/zelo redko."

The subjects for the tests were secondary and post-secondary students in Ljubljana, totalling 186 at high school and 180 at university; ${ }^{8}$ each subject provided personal details, see 4.2. For the 1994 follow-up study I limited the tests to three groups of respondents, totalling 116 in all. ${ }^{9}$

In the 1993 tests, all of questions (1) - (4) were asked. In the 1994 follow-up study, only questions (1) and (3) were asked (for rationale, see 3.3). Apart from answering questions (1) - (4) with reference to both sets of 33 verbs selected as cues, the 1993 subjects performed other tasks connected both with these verbs and (as "distractor tasks") with completely different cues; in 1994, they performed no other tasks. In each successive test, in both years, the order of cues was varied to minimize any "order effect"; and before the first test with -eti verbs and in the first test with -iti verbs, a short explanation was provided to ensure that the subjects would

\footnotetext{
${ }^{7}$ See footnote 4 for previous use of the first three questions by linguists investigating productivity.

${ }^{8}$ For details, see footnote 2 .

${ }^{9}$ The three groups were in the Oddelek za farmacijo Fakultete za naravoslovje in tehnologijo; the Biotehniška fakulteta; and the Pedagoška akademija.
} 
know, from the start, that they were to make judgments about inchoative and factitive verbs. ${ }^{10}$ One specific sub-routine to tests involving question (2) was incorporated to try to investigate what is known as "blocking." This sub-routine, and its analysis, are described in $\mathbf{3 . 4}$.

\subsection{Analysis}

All the responses were scored, respectively, 5, 4, 3, 2 and $1 ; 11$ this implies that the mean scores displayed in the tables and discussed below may be interpreted as follows for questions (1) through (4):

Question 1: the higher the mean score for a verb, the more did the students consider that the verb belonged to Standard Slovene;

Question 2: the higher the mean score for a verb, the more did the students believe that they personally used that verb;

Question 3: the higher the mean score for a verb, the more did the students assess that verb as a possible and understandable verb;

Question 4: the higher the mean score for a verb, the more frequently did the students estimate that they themselves used that verb.

The results are of different kinds and provide evidence not only about productivity but also about other phenomena. Results with a bearing on productivity are described in section 3., and other results in section 4. Much more could be written about individual results than what follows. For example, dreveneti and dreveniti received generally similar ratings for questions (1), (2) and (3), but very different ratings for questions (4). Why should this have happened?

First, however, the overall results may be inspected, i.e., the means of all the means. These are set out on Table I, where it can be observed - for both -eti and -iti derivations - that, overall, the subjects had higher average rankings on question (3) than on (1), and higher on (1) than on (2). This is as expected: namely, that speakers of the language will accept more words as "possible and understandable" (3) than those they believe to be "standard" (1), while they will believe that they themselves actually use fewer (2) words than those they believe to be "standard" (1). For all three questions, also, subjects ranked derivations in -iti higher than they ranked -eti derivations; this may reflect the higher productivity of -iti, see further below.

${ }^{10}$ Viz., respectively: "Vse sledeče besede so glagoli na -eti, ki pomenijo 'postajati nekaj'. Na primer, beleti pomeni 'postajati bel', in bogateti pomeni 'postajati bogat'," and "Vse sledeče besede so glagoli na -iti, ki pomenijo 'narediti, da nekaj postane drugače'. Na primer, obeliti pomeni 'narediti nekaj belo', in bogatiti pomeni 'narediti koga bogatega'."

${ }^{11}$ Analysis was performed with the SPSS statistical package. I am indebted to Darrell Williams for help in the final stages of this analysis. 
Table I. Means of Means

\begin{tabular}{lcccc}
\hline Questions: & (1) “Standard?” & (2) “Use?” & (3) “Possible?” & (4) “Frequent?” \\
\hline -et $i$ cues & 3.12 & 2.63 & 3.46 & 3.79 \\
-iti cues & 3.20 & 2.91 & 3.52 & 3.46 \\
\hline
\end{tabular}

\section{Results: Productivity}

\subsection{Productivity as a cline}

It is frequently emphasized that productivity is a cline, i.e., is a matter not of "either/or" but of "more or less." As is not always made clear, this must be understood in two senses. First and most obviously (see Bauer 1988: 57-60), one process may be synchronically more productive than another; so, English -th is a much less productive nominalizing suffix than -ity, ${ }^{12}$ and in Slovene -oba is a much less productive nominalizing suffix than -ost. Second, what may be called the productive strength of any one process also varies. This variation is well illustrated in Tables II-III; to take just two examples from the mean responses to question (3) "Possible?" we see that godneti was assessed, on average, as extremely "possible and understandable," while at the other end of the scale plašeti was assessed, on average, as well nigh impossible and incomprehensible; and the other thirty-one cues are strung out along the cline in between the two. The same is true for the reponses to the other three questions. It is clear that the subjects, in general, considered the verbal cues, variously, to belong more or less to Standard Slovene; to be generally used more or less; to be more or less possible and understandable; and they thought that they personally used them more or less frequently. This is, of course, what would be expected intuitively, but has not been demonstrated before for Slovene.

It is even more interesting to inspect the ratings given in each set of answers for individual verbs. These can be seen on Tables IV-V. What is striking is the amount of inconsistency among the four lists. No verb is ranked very high on all four lists; no verb (with the possible exception of pomnogoteriti) is ranked very low on all four. Most verbs, indeed, receive a thorough mixture of high and low rankings; it may be asked - to use the same example - why the subjects should have considered that godneti, while receiving a high rating for belonging to Standard Slovene and for comprehensibility, should be assessed as being used infrequently not only by the subjects themselves, but by Slovene speakers in general. Inconsistencies like this are, indeed, the rule. They may appear anomalous, but given the large number of subjects who participated in the experiments they must be accepted as valid, at least for speakers of Slovene in their late teens and early twenties. ${ }^{13}$ The differences in results can perhaps be explained by the semantics of the individual verbs and their function in the language. ${ }^{14}$

${ }^{12}$ Bauer refers to - th as "unproductive." In the 1960s, however, the neologism coolth was considered acceptable in some styles of English, and it may be that this suffix is still not totally unproductive.

${ }^{13}$ The subjects' average ages were 18.06 (high school) and 21.33 (university classes).

${ }^{14}$ The wide differences in the responses to these four questions are of interest for psycholinguistic testing in general, for questions of "acceptability" and "grammaticality" are frequently featured in such tests, but with little attention to what the questions actually imply. 
Table II. Mean Responses to Questions (1) through (4), -eti Verbs Ranked in Numerical Order

Questions:

(1) "Standard?"

(2) "Use?"

(3) "Possible?"

(4) "Frequent?"

\begin{tabular}{|c|c|c|c|c|c|c|c|}
\hline otolsteti & 4.95 & rjaveti & 4.75 & godneti & 4.95 & debeleti & 4.74 \\
\hline nemeti & 4.82 & medleti & 4.23 & leneti & 4.92 & prestareti & 4.68 \\
\hline godneti & 4.60 & hrometi & 4.10 & kosmateti & 4.56 & nemeti & 4.61 \\
\hline žolteti & 4.31 & trdeti & 3.83 & prestareti & 4.47 & osmeleti & 4.58 \\
\hline rjaveti & 4.23 & dreveneti & 3.76 & čvrsteti & 4.40 & apneneti & 4.55 \\
\hline ogrobeti & 4.15 & čvrsteti & 3.72 & pogrdeti & 4.28 & jekleneti & 4.54 \\
\hline apneneti & 3.99 & debeleti & 3.32 & apneneti & 4.18 & hrometi & 4.46 \\
\hline plašeti & 3.85 & nemeti & 3.16 & mrtveti & 4.15 & globeti & 4.44 \\
\hline globeti & 3.78 & jekleneti & 3.14 & osmeleti & 4.06 & srepeti & 4.44 \\
\hline kasneti & 3.67 & kosmateti & 2.83 & kruteti & 3.92 & suroveti & 4.36 \\
\hline porevneti & 3.42 & suroveti & 2.83 & goleti & 3.89 & rjaveti & 4.34 \\
\hline plitveti & 3.26 & kasneti & 2.82 & samotneti & 3.74 & žolteti & 4.29 \\
\hline kosmateti & 3.21 & mrtveti & 2.81 & pobedasteti & 3.67 & bakreneti & 4.27 \\
\hline prestareti & 3.18 & bakreneti & 2.68 & suroveti & 3.60 & kruteti & 4.28 \\
\hline bakreneti & 3.17 & srepeti & 2.63 & globeti & 3.59 & čvrsteti & 4.25 \\
\hline debeleti & 2.99 & apneneti & 2.48 & plitveti & 3.45 & medleti & 4.25 \\
\hline srepeti & 2.91 & pogrdeti & 2.44 & nemeti & 3.42 & ogrobeti & 4.17 \\
\hline dreveneti & 2.88 & plitveti & 2.43 & mrzleti & 3.32 & porevneti & 4.04 \\
\hline mrtveti & 2.73 & leneti & 2.30 & porevneti & 3.20 & pobedasteti & 3.87 \\
\hline kruteti & 2.62 & prestareti & 2.26 & debeleti & 3.17 & pogrdeti & 3.69 \\
\hline samotneti & 2.58 & samotneti & 2.24 & ogrc & 3.10 & goleti & 3.66 \\
\hline leneti & 2.57 & ogrobeti & 2.17 & medleti & 3.08 & kosmateti & 3.64 \\
\hline jekleneti & 2.50 & otolsteti & 2.15 & bakreneti & 3.00 & plitveti & 3.59 \\
\hline osmeleti & 2.49 & kruteti & 2.12 & dreveneti & 2.99 & otolsteti & 3.56 \\
\hline suroveti & 2.43 & goleti & 2.10 & srepeti & 2.97 & kasneti & 3.55 \\
\hline pogrdeti & 2.41 & pobedasteti & 2.01 & kasneti & 2.95 & mrtveti & 3.34 \\
\hline goleti & 2.39 & mrzleti & 1.92 & žolteti & 2.93 & leneti & 3.09 \\
\hline pobedasteti & 2.37 & žolteti & 1.87 & jekleneti & 2.80 & trdeti & 2.91 \\
\hline mrzleti & 2.36 & porevneti & 1.82 & hrometi & 2.73 & samotneti & 2.46 \\
\hline medleti & 2.28 & globeti & 1.71 & otolsteti & 2.48 & plašeti & 2.44 \\
\hline čvrsteti & 2.06 & plašeti & 1.50 & trdeti & 2.36 & mrzleti & 2.27 \\
\hline hrometi & 1.99 & osmeleti & 1.44 & rjaveti & 2.27 & godneti & 2.08 \\
\hline trdeti & 1.76 & godneti & 1.43 & plašeti & 1.63 & dreveneti & 1.59 \\
\hline
\end{tabular}


Table III. Mean Responses to Questions (1) through (4), -iti Verbs Ranked in Numerical Order

Questions:

(1) "Standard?"

(2) "Use?"

(3) "Possible?"

(4) “Frequent?"

\begin{tabular}{|c|c|c|c|c|c|c|c|}
\hline izljubiti & 4.72 & ledeniti & 4.73 & blažiti & 4.60 & rjaviti & 4.91 \\
\hline porevniti & 4.69 & slabotniti & 4.72 & jasniti & 4.41 & ogrditi & 4.75 \\
\hline tesniti & 4.67 & sladiti & 4.66 & sladiti & 4.32 & grobiti & 4.69 \\
\hline slabotniti & 4.66 & blažiti & 4.60 & tesniti & 4.31 & izljubiti & 4.69 \\
\hline ledeniti & 4.20 & tujiti & 4.17 & onečistiti & 3.84 & glušiti & 4.61 \\
\hline mrtviti & 4.15 & onečistiti & 4.08 & ožiti & 3.55 & blažiti & 4.53 \\
\hline poočititi & 4.10 & besniti & 3.85 & ledeniti & 3.53 & blazniti & 4.35 \\
\hline jekleniti & 4.01 & rjaviti & 3.76 & oleseniti & 3.35 & bahatiti & 4.27 \\
\hline sladiti & 4.01 & glušiti & 3.72 & rjaviti & 3.33 & postekleniti & 4.27 \\
\hline tujiti & 4.00 & srepiti & 3.51 & besniti & 3.28 & dreveniti & 4.19 \\
\hline onečistiti & 3.98 & blazniti & 3.48 & postekleniti & 3.24 & drobniti & 4.15 \\
\hline rjaviti & 3.97 & poočititi & 3.43 & leniti & 3.24 & siviti & 4.00 \\
\hline huditi & 3.92 & kisliti & 3.33 & siviti & 3.13 & sladiti & 3.77 \\
\hline osmeliti & 3.89 & ožiti & 3.32 & tujiti & 2.92 & slabotniti & 3.75 \\
\hline ožiti & 3.80 & zanoviti & 3.28 & izljubiti & 2.90 & tesniti & 3.73 \\
\hline srepiti & 3.78 & dreveniti & 3.25 & dreveniti & 2.89 & zanoviti & 3.69 \\
\hline zanoviti & 3.62 & jekleniti & 3.25 & glušiti & 2.85 & srepiti & 3.68 \\
\hline jasniti & 3.55 & grobiti & 3.14 & blazniti & 2.84 & kisliti & 3.61 \\
\hline blazniti & 3.53 & porevniti & 3.14 & kisliti & 2.84 & huditi & 3.55 \\
\hline glušiti & 3.44 & leniti & 2.98 & jekleniti & 2.76 & porevniti & 3.48 \\
\hline ogrditi & 3.29 & ogrditi & 2.86 & mrtviti & 2.74 & jasniti & 3.31 \\
\hline blažiti & 3.21 & tesniti & 2.83 & slabotniti & 2.50 & jekleniti & 3.31 \\
\hline siviti & 3.20 & bahatiti & 2.79 & drobniti & 2.47 & tujiti & 3.23 \\
\hline pomnogoteriti & i 3.01 & drobniti & 2.73 & porevniti & 2.41 & leniti & 2.91 \\
\hline grobiti & 2.95 & jasniti & 2.71 & ogrditi & 2.33 & osmeliti & 2.91 \\
\hline bahatiti & 2.92 & mrtviti & 2.49 & srepiti & 2.32 & ledeniti & 2.79 \\
\hline postekleniti & 2.85 & postekleniti & 2.44 & huditi & 2.24 & mrtviti & 2.72 \\
\hline besniti & 2.60 & huditi & 2.37 & pomnogoteriti & $i 2.21$ & besniti & 2.63 \\
\hline oleseniti & 2.57 & pomnogoteriti & 2.34 & grobiti & 2.20 & oleseniti & 1.72 \\
\hline kisliti & 2.47 & oleseniti & 2.00 & bahatiti & 2.05 & poočititi & 1.63 \\
\hline drobniti & 2.30 & osmeliti & 1.95 & poočititi & 1.80 & pomnogoteriti & i 1.51 \\
\hline dreveniti & 2.18 & izljubiti & 1.91 & osmeliti & 1.32 & ožiti & 1.51 \\
\hline leniti & 2.02 & siviti & 1.85 & zanoviti & 1.31 & onečistiti & 1.29 \\
\hline
\end{tabular}


Table IV. Mean Responses to Questions (1) through (4), -eti Verbs Ranked Alphabetically According to Dictionary Entry

Questions:
(1) "Standard?"
(2) "Use?"
(3) "Possible?" (4) "Frequent?"

1. verbs with no kvalifikatorji

$\begin{array}{lllll}\text { dreveneti } & 2.88 & 3.76 & 2.99 & 1.59 \\ \text { hrometi } & 1.99 & 4.10 & 2.73 & 4.46 \\ \text { medleti } & 2.28 & 4.23 & 3.08 & 4.25 \\ \text { mrtveti } & 2.73 & 2.81 & 4.15 & 3.34 \\ \text { nemeti } & 4.82 & 3.16 & 3.42 & 4.61 \\ \text { prestareti } & 3.18 & 2.26 & 4.47 & 4.68 \\ \text { rjaveti } & 4.23 & 4.75 & 2.27 & 4.34 \\ \text { trdeti } & 1.76 & 3.83 & 2.36 & 2.91\end{array}$

2. verbs with kvalifikator $(\mathrm{k})$

$\begin{array}{lllll}\text { apneneti } & 3.99 & 2.48 & 4.18 & 4.55 \\ \text { bakreneti } & 3.17 & 2.68 & 3.00 & 4.27 \\ \text { kasneti } & 3.67 & 2.82 & 2.95 & 3.55 \\ \text { plitveti } & 3.26 & 2.43 & 3.45 & 3.59 \\ \text { pobedasteti } & 2.37 & 2.01 & 3.67 & 3.87 \\ \text { pogrdeti } & 2.41 & 2.44 & 4.28 & 3.69 \\ \text { srepeti } & 2.91 & 2.63 & 2.97 & 4.44 \\ \text { suroveti } & 2.43 & 2.83 & 3.60 & 4.36\end{array}$

3. verbs with other kvalifikatorji

$\begin{array}{lllll}\text { čvrsteti (r) } & 2.06 & 3.72 & 4.40 & 4.25 \\ \text { debeleti (r) } & 2.99 & 3.32 & 3.17 & 4.74 \\ \text { globeti (z) } & 3.78 & 1.71 & 3.59 & 4.44 \\ \text { godneti (r) } & 4.60 & 1.43 & 4.95 & 2.08 \\ \text { goleti (r) } & 2.39 & 2.01 & 3.89 & 3.66 \\ \text { jekleneti (r) } & 2.50 & 3.14 & 2.80 & 4.54 \\ \text { kosmateti (r) } & 3.21 & 2.83 & 4.56 & 3.64 \\ \text { mrzleti (k,r) } & 2.36 & 1.92 & 3.32 & 2.27 \\ \text { ogrobeti (k,r) } & 4.15 & 2.17 & 3.10 & 4.17 \\ \text { otolsteti (k,r) } & 4.95 & 2.15 & 2.48 & 3.56 \\ \text { žolteti (s) } & 4.31 & 1.87 & 2.93 & 4.29\end{array}$

4. "made-up" verbs

\begin{tabular}{lllll} 
kruteti & 2.62 & 2.12 & 3.92 & 4.28 \\
leneti & 2.57 & 2.30 & 4.92 & 3.09 \\
osmeleti & 2.49 & 1.44 & 4.16 & 4.58 \\
plašeti & 3.85 & 1.50 & 1.63 & 2.44 \\
porevneti & 3.42 & 1.82 & 3.20 & 4.04 \\
samotneti & 2.58 & 2.24 & 3.74 & 2.46 \\
\hline
\end{tabular}


Table V. Mean Responses to Questions (1) through (4), -iti Verbs Ranked Alphabetically According to Dictionary Entry

Questions:
(1) "Standard?"
(2) "Use?"
(3) "Possible?" (4) "Frequent?"

1. verbs with no kvalifikatorji

$\begin{array}{lllll}\text { dreveniti } & 2.18 & 3.25 & 2.89 & 4.19 \\ \text { glušiti } & 3.44 & 3.72 & 2.85 & 4.61 \\ \text { jasniti } & 3.55 & 2.71 & 4.41 & 3.31 \\ \text { mrtviti } & 4.15 & 2.49 & 2.74 & 2.72 \\ \text { ogrditi } & 3.29 & 2.86 & 2.33 & 4.75 \\ \text { onečistiti } & 3.98 & 4.08 & 1.29 & 1.29 \\ \text { ožiti } & 3.80 & 3.32 & 3.55 & 1.51 \\ \text { rjaviti } & 3.97 & 3.76 & 3.33 & 4.91 \\ \text { sladiti } & 4.01 & 4.66 & 4.32 & 3.77 \\ \text { tesniti } & 4.67 & 2.83 & 4.31 & 3.73 \\ \text { zanoviti } & 3.62 & 3.28 & 1.31 & 3.69\end{array}$

2. verbs with kvalifikator $(\mathrm{k})$

$\begin{array}{lllll}\text { blazniti } & 3.53 & 3.48 & 2.84 & 4.35 \\ \text { jekleniti } & 4.01 & 3.25 & 2.76 & 3.31 \\ \text { kisliti } & 2.47 & 3.33 & 2.84 & 3.61 \\ \text { leniti } & 2.02 & 2.98 & 3.24 & 2.91 \\ \text { siviti } & 3.20 & 1.85 & 3.13 & 4.00\end{array}$

3. verbs with other kvalifikatorji

$\begin{array}{lllll}\text { bahatiti (r) } & 2.95 & 2.79 & 2.05 & 4.27 \\ \text { besniti (r) } & 2.60 & 3.85 & 3.28 & 2.63 \\ \text { blažiti (r) } & 3.21 & 4.60 & 4.60 & 4.53 \\ \text { huditi (z) } & 3.92 & 2.37 & 2.24 & 3.55 \\ \text { izljubiti }(\mathrm{k}, \mathrm{r}) & 4.72 & 1.91 & 2.90 & 4.69 \\ \text { ledeniti }(\mathrm{k}, \mathrm{r}) & 4.20 & 4.73 & 3.53 & 2.79 \\ \text { osmeliti }(\mathrm{z}) & 3.89 & 1.95 & 1.32 & 2.91 \\ \text { pomnogoteriti (s) } & 3.01 & 2.34 & 2.21 & 1.51 \\ \text { poočititi (z) } & 4.10 & 3.43 & 1.80 & 1.63 \\ \text { postekleniti }(\mathrm{k}, \mathrm{r}) & 2.85 & 2.44 & 3.24 & 4.27 \\ \text { tujiti }(\mathrm{k}, \mathrm{r}) & 4.00 & 4.17 & 2.92 & 3.23\end{array}$

4. "made-up" verbs

$\begin{array}{lllll}\text { drobniti } & 2.30 & 2.73 & 2.47 & 4.15 \\ \text { grobiti } & 2.95 & 3.14 & 2.20 & 4.69 \\ \text { oleseniti } & 2.57 & 2.00 & 3.35 & 1.72 \\ \text { porevniti } & 4.69 & 3.14 & 2.41 & 3.48 \\ \text { slabotniti } & 4.66 & 4.72 & 2.50 & 3.75 \\ \text { srepiti } & 3.78 & 3.51 & 2.31 & 3.68\end{array}$




\subsection{The relevance of frequency}

The importance of the relative frequency of DPs in speakers' lexicons is undeniable: if a derivative pattern is productive, it will probably have been productive for some time, and this will be mirrored in dictionaries and in speakers' own lexica. Moreover, the existence of larger and smaller stocks of words that utilize different derivative patterns must in turn have some influence on these patterns' productivity. Over two decades ago Aronoff (1976: 35) emphasized that type frequency of words based on a given DP did not accurately reflect the productivity of that DP. The situation in Slovene, where the number of factitively derivated verbs appears to be greater than that of inchoatively derived verbs (see above), may merely be an accident of history that does not reflect synchronic psycholinguistic processes. It may rather (or, also) be due to constraints (see 3.4) on the applicability of the DPs, whereby (and I speculate!) - $e$ - may be fully productive within the limitations set by these constraints, whereas $-i$ - is only partly productive while yet being limited by fewer constraints; which could perhaps be why -iti verbs occur more frequently in dictionaries. More recently, it has been very convincingly argued (see Baayen and Lieber 1991, Baayen 1993) that token frequency can provide a more accurate measure: if a process is very productive, it will be used that more frequently to "coin new formations," and so there will be more instances of new words being thus coined on the spur of the moment and used relatively seldom. Baayen and Lieber go so far, indeed, as to develop a measure which requires a count of hapax legomena (derivations that are used only once) in a language corpus. - A large corpus of the kind that they use ${ }^{15}$ is, however, not available for Slovene; hence my recourse to classifying the verbs separately, depending on the provision of indicators in the $S S K J$, see above. On Tables IV-V the mean scores are displayed in four groups: verbs without indicators in the SSKJ, as defined above; verbs labelled as "bookish"; verbs with other indicators; and made-up verbs. Let us inspect the mean responses in the fourth column of each of these tables, the results for responses to question (4). When we contrast the first three groups on the one hand with the fourth on the other, i.e., the results for the 27 "real" verbs with those for the 6 "made-up" verbs, it is clear that the subjects were of the opinion, in general, that they used most of the "made-up" verbs with considerable frequency.

Now it must be admitted that just because these verbs are not in the SSKJ it does not mean that they have not been used before and are not thus "occurrent" in Slovene; indeed, although I did literally devise the verbs, there is evidence of previous use for some of them: of the six "made-up" verbs in -eti, one is in Pleteršnik (1894), namely leneti 'faulenzen'; and possible related derivatives for two more, viz. osmeljevati and plašenje, are in Besedišče 1987; while of the six in -iti, three are in Besedišče 1987, namely grobiti, oleseniti, srepiti. (Since the Besedišče does not gloss its forms, these comments are speculative, for it is not clear whether these words have inchoative/factitive, or other meanings.) Still, the ratings for other "made-up" verbs are high - especially those for kruteti and also porevneti (Table IV) and drobniti (Table V), and I have found no published evidence of these verbs' existence.

\footnotetext{
${ }^{15}$ Their corpus is the 'Celex database' of texts comprising over 18 million English words (Baayen and Lieber 1991: 803).
} 
Let us now reconsider questions (1) and (3). A response to "Ali se po vašem beseda nahaja v knjižni slovenščini?" shows whether the subject thinks the verb belongs to Standard Literary Slovene - i.e., that it will be used on formal occasions and in the official media, and that it will be listed in official dictionaries. Responses, on the other hand, to "Ali je ta beseda po vašem možna in razumljiva?" constitute a direct testimony to the subjects' appreciation of the verb’s availability to their own selves. Question (3), then, provides the best first indication of the productivity of the DPs; for if productivity is (see above) "the possibility for language users to coin, unintentionally, a number of formations," these formations must necessarily be both "possible" and "understandable." - When we constrast the results for questions (3) and (4), we see how very different they are. For example, on Table IV, both rjaveti and hrometi are rated as not very possible and understandable, but the subjects considered that they used them very frequently. These results emphasize how very different are productivity and frequency.

\subsection{Towards a Test for Productivity}

Let us consider again questions (1) through (3). Greenbaum and Quirk (1970) argue that answers to these three questions will reflect three different kinds of evaluation, namely what they term, respectively, (1) "recognition of a precept," (2) "belief about own use," and (3) "willingness to tolerate." Of these, the first reflects subjects' assessments of the standard grammatical prescriptions that are recognized in the linguistic community; the second reflects their assessments of their own active use of the language; and the third reflects their assessments of their passive acceptance of linguistic usage.

The first parameter - "recognition of a precept" - will depend enormously on the existence in the linguistic commmunity of recognized precepts, their prestige in the community, and the extent to which they are known in that community. I suggest that, for example, Slovenes' attitudes to Standard Slovene will be different from the attitudes of North Americans or of Britons to Standard English, and also that these different linguistic communities will not all be equally aware of the respective standardized norms. The results described for the Slovene respondents in 4.2 may be very different from comparable results that could be obtained in Anglophone communities.

Here, however, we will explore a proposed test for productivity which utilizes the means of responses to questions (3) and (2), which are abbreviated here as $\mathbf{p}$ (for "possible") and $\mathbf{u}$ (for "used") respectively. This is based on an analysis which has, as its point of departure, the assumption that, normally, $\mathbf{p}$ judgements will be higher than $\mathbf{u}$ judgements: i.e., that in speakers' opinions they understand more words than they actually use - that their passive vocabulary is larger than their active vocabulary. The approach reflects the finding by Baayen (see 3.2) that more productive derivative processes result in more hapax legomena, that is, more words glossed only once in a corpus - more types occurring with only one token - and less productive derivative processes result in fewer such words; or, more generally, that "unproductive affixes show a large proportion of high-frequency types and ... productive ones a much lower proportion" (Lieber 1992: 4). 
With respect to real versus made-up words, I interpret this as follows. For real words, the difference between p-ratings and u-ratings for our two DPs may be significant, but will not be very marked, because we are dealing with words which speakers may well have used and most of which will therefore tend to be in their active vocabularies. This difference can be expected to be greater for the (presumedly) more productive suffix -iti, and smaller for the (presumedly) less productive suffix -eti, because speakers will tend to consider more of their "passive vocabulary" words with the former suffix as "possible and understandable" - hapax legomena with this suffix occur more often! - but this will not hold so true for the latter.

For made-up words, on the other hand (to the extent that they are truly "made-up," see 3.2 and below), and for both DPs, the u-ratings will be much lower, both in relation to the same scale for real words, and in relation to the p-ratings for made-up words. The important point is the following. If a DP is more productive, its "use" rating will not be quite as low, because speakers will be more accustomed to words formed with that derivative process, and the made-up words will sound more plausible; hence, the "use" rating for made-up words with the more productive derivative process will be closer to the "possibility" rating for the same words. The difference between the two ratings will however be greater for a less productive (and therefore less familiar) DP.

This analysis therefore involved calculations of $\mathbf{p}$ and $\mathbf{u}$ separately for "real words" and "made-up words." On Table VI are displayed the calculations according to the formula $(\mathbf{p}-\mathbf{u}) \div \mathbf{u}$, which expresses the amount by which (on average) the responses to Question 3 exceed the responses to Question 1 in our experiments in Ljubljana in 1993. As is apparent, for real words, the figure for -iti verbs is only slightly higher than for -eti verbs. In contrast, the figure for made-up words is much higher for -eti verbs than for -iti verbs.

Table VI: Productivity Formula as Applied to Results from Tests in Ljubljana 1993

\begin{tabular}{lllll}
\hline & \multicolumn{2}{l}{ Actual Words } & \multicolumn{2}{l}{ Made-up Words } \\
\cline { 2 - 5 } & -eti & -iti & -eti & -iti \\
\cline { 2 - 5 }$(\mathbf{p}-\mathbf{u}) \div \mathbf{u}$ & 0.224 & 0.251 & 0.884 & 0.374 \\
\hline
\end{tabular}

In other words: where real words are concerned, the difference between p-ratings and $\mathbf{u}$-ratings is greater for -iti, which is therefore the more productive suffix. Where made-up words are concerned, on the other hand, the difference between p-ratings and $\mathbf{u}$-ratings is greater for -eti, which is therefore the less productive suffix.

This is a very neat result; perhaps too neat. There are three problems that have to be taken into consideration, and which may affect either the analytical approach, or its specific applications, or both. First, one must always be aware of the co-occurrence of the constraint known as blocking, see 3.4 below; to the extent that this constraint operates, it will affect less productive DPs more than more productive ones: it has been suggested, even, that totally productive DPs can never be 
blocked. Moreover, blocking will affect the "use" evaluation more than the "possibility" evaluation. Second, the "made-up" words numbered only six, which makes the result relatively unreliable. Third, I risked "making up" words which do in fact occur, even if they are not glossed in the SSKJ; and, as shown above, I may indeed have managed to "devise" words that already existed. To the extent that this actually happened, real words will have been, by chance, included in the list of (so-called) "made-up" ones. The words glossed by Pleteršnik and in the Besedišče could of course have been omitted from analysis, but even if I were sure of their meaning (and thus of their status as inchoative or factitive derivations) this would leave too small number of "made-up" words for a useful comparison. ${ }^{16}$

Nevertheless, the results as displayed in Table VI were encouraging. It was for this reason that I decided to replicate the tests with questions (3) and (2) in Ljubljana in 1994. The results were as on Table VII. They strongly support our hypothesis. I suggest that the numerical imbalances between the figures on Tables VI and VII may derive from the different proportions of "made-up" words in the 1993 and 1994 tests, and perhaps from the different influence of specific "blocking" factors.

Table VII. Productivity Formula as Applied to Results from Tests in Ljubljana in 1994

\begin{tabular}{lllll}
\hline & \multicolumn{2}{l}{ Actual Words } & \multicolumn{2}{l}{ Made-Up Words } \\
\cline { 2 - 5 }$(\mathbf{p}-\mathbf{u}) \div \mathbf{u}$ & 0.108 & $-i t i$ & -eti & -iti \\
\cline { 2 - 5 } & 0.178 & 0.394 & 0.148 \\
\hline
\end{tabular}

Nevertheless, the reservations listed above still hold. To prove the reliability of the $(p-u) \div u$ measure, it will be necessary to replicate these tests using very many more cues, including (as in the 1994 test) a greater proportion of "made-up" words.

\section{4 "Blocking"}

It is acknowledged that one major obstacle to progress in research into derivational productivity is the lack of a proper understanding of the forces that impede derivation. Even very productive DPs do not apply to every single form, ${ }^{17}$ and enough is known of the obstacles to derivation for it to be clear that they are of great significance. There are several kinds of obstacles, both formal (e.g. Slovene -ski can only be suffixed to stems ending in consonants; Slavic *-ba could not be suffixed to stems ending in labials, see Browne (1981)) and semantic. Among semantic obstacles is what is now usually called blocking. ${ }^{18}$ An often-cited example is the English deverbal suffix $-e r$ which, though productive, is not normally affixed to, e.g., type to produce a derivative *typer meaning "person who types"; it is argued

\footnotetext{
${ }^{16}$ Another solution - asking native speakers if these words existed - was an integral part of the experiment, and was therefore not resorted to a priori.

${ }^{17}$ This statement applies to the languages in which DPs have been studied, which are apparently all Indo-European and typologically similar.

${ }^{18}$ The idea is not new: Hermann Paul identified it in 1896 (see Reiner 1988: 155). The term blocking was proposed by Aronoff (1976); a less used but more precise term is pre-emption.
} 
that the prior existence of the word typist pre-empts, or blocks, this derivation; in Slovene, similarly, one could argue that the derivation of *tipkalec is "blocked" by the prior existence of tipkar. In the current state of uncertainty about blocking, ${ }^{19}$ one theme keeps recurring: namely, that there should be some link, perhaps even some correlation, between blocking and frequency. Thus Aronoff (1976: 43), "there is a ... direct connection between lexical listing and ... blocking"; and at the very least it is likely that the more productive a DP is, the more hapax legomena will be derived, hence the less blocking will occur. For these reasons, a sub-routine was devised to investigate blocking:

Some of the students - a total of 123 in all - who completed the questionnaire with question (2) "Use?" were asked to do a supplementary task. Each, as with all these tests, circled one of the five responses with respect to "Use?" If they had circled $\mathbf{c}, \mathbf{d}$ or $\mathbf{e}-$ i.e., if it was their judgment that they did not use the word very much or at all - then they were asked to write down which word they preferred instead of that verb. ${ }^{20}$ The analysis of these "write-in" parts of the test was conducted as follows. First, the "written-in" forms were classified as valid replacements, or rejected, using four criteria: (1) Wherever subjects had circled a or b, their "written-in" forms were ignored, however interesting they seemed: after all, if a subject said they used a particular verb, I could not accept that its use was "blocked". (2) What may be called "empty" aspectual counterparts of verbs were ignored. Example: responses from the 4 subjects who said they did not use goleti and who wrote in ogoleti as the preferred alternative were ignored, since these two forms must be considered as belonging to the same verb: in the SSKJ goleti = postajati gol; ogoleti $=$ postati gol . This information may be of interest to aspectologists, but is irrelevant to studies of "blocking." (3) When subjects clearly did not understand either the instructions, or the verbal cue, their answers were ignored. Examples: godrnjati 'to grumble' for godneti 'to become mature' (here, the instructions were presumably misunderstood); and ne imeti več rad 'not to love any longer' for izljubiti 'to love to an extreme' (here the cue was obviously unfamiliar and was misinterpreted). (4) A valid replacement had to be semantically similar to the form which it was replacing, at least to the extent that it could be considered a potential synonym in some normal context. This criterion was interpreted liberally; so, e.g., two suggested replacements for globeti 'to sink' were considered valid: globiti se, whose normal meaning is 'to become more sensitive', was accepted as valid because it could be interpreted literally as 'to make oneself deeper'; and nizati se 'to lower oneself' was accepted because 'lowering oneself' would be synonymous with 'sinking' if one were in water. Phrases were included: e.g., dobivati bakreni lesk 'to get a coppery sheen' was considered a valid replacement for bakreneti 'to become coppery.' Next, replacements were classified in two groups: single words (whereby reflexive verbs were counted as one-word units); and replacements of more than one word, i.e., "paraphrases." Ex-

\footnotetext{
${ }^{19}$ For this uncertainty, compare Marle (1985: 63) who calls for a systematic investigation of "impeding forces"; Di Sciullo and Williams (1987: 13), "it remains a mystery what blocking really is"; and Bauer (1988: 67), "it rather looks as if blocking is not strictly relatable to derivational morphology." See also Rainer 1988. ljali."

${ }^{20}$ The instruction: "Če ste obkrožili c, d ali e, napišite besedo ali frazo, ki jo bi rajši uporab-
} 
amples: for debeleti 'to become fat' - one-word synonyms: debeliti se, rediti se, zrediti se; paraphrases: postajati debel 'to become fat' and dobivati meso 'to gain flesh'.

The results are set out in Table VIII. In the left-hand column are the cues, listed in numerical order of means as on Table II. In column A the numeral shows the number of times a single synonymous word was entered by the students. In column $B$ is a numeral showing the number of times a synonymous paraphrase was suggested. Since "blocking", to the extent that it exists and operates, involves the restrictive influence of words and not of paraphrases (otherwise, few if any new words would ever be derived!), I considered single synonyms as potential examples of "blocking," and paraphrases as instances where "blocking" was (for an individual respondent) inoperative.

The table suggests several conclusions, chief among which (unfortunately) is that if there is a pattern to "blocking," it is not made evident by this test. It is clear that some common words have potential "blocking" synonyms, and some uncommon words do not; it is clear that frequency of use and "blocking" are rather vaguely correlated; but neither of these conclusions is new. The results are not uninformative, however. It should be noted that several of the "made-up" words were understood as inchoatives or factitives, respectively, by most of the repondents: for instance, 59 students (48 of the total), nearly all those who rejected the derivative leneti, wrote in words and paraphrases which conveyed the idea of "becoming lazy," (e.g., polenariti, polenjati se, bolj je len, lena sem ko fuks); see also the figures for samotneti, kruteti, porevneti, plašeti, drobniti; on the other hand, slabotniti, porevniti, srepiti and grobiti were either not understood as factitives, or if they were, the task of devising a synonymous expression was too difficult for the respondents. Moreover, whereas the derivation of leneti can be considered "blocked" by the prior existence of such words as polenariti, the same can definitely not be said of the derivation of kruteti: the verb was rejected by a majority of respondents, but only one thought of a synonymous word ( $k r u t i t i$ se) whereas 49 suggested paraphrases (otrdeti $v$ srcu, biti krutejši, biti okruten, etc.). If this particular test is replicated with a large number of "made-up" words, it should be very informative about the role played by "blocking," for it should become clear to what extent there are already-existing words which pre-empt the role of potential derivatives.

One other matter of interest, deriving from Table VIII, is mentioned in 4.1.

\section{Other Results} tion.

Two more results, both incidental to the question of productivity, deserve men-

\subsection{Indicators of frequency in the SSKJ}

In addition to the comments on frequency in 3.2, above, two other important points should be made: one is apparent from Tables IV-V, the second from Table VIII. First, note that on Table I we see that the subjects tended to rate their own use of verbs (question (4)), in general, as more rather than less frequent: the mean for all 33 -eti verbs is 3.79 , and the mean for all 33 -iti verbs is 3.46 , in both instances much higher than the "povprečno" rating which was scored at 3.00. When we compare, on Table IV, means for question (4) on the one hand for verbs without indi- 
Table VIII. "Replacements" for Verbal Cues Rated "Not Used"

$\mathbf{A}=$ number of one-word replacements (tokens)

B $=$ number of paraphrase-type replacements (tokens)

in bold: verbs marked "redko" in the SSKJ

in italics: "made-up" words

\begin{tabular}{|c|c|c|c|c|c|c|c|}
\hline & \multicolumn{3}{|c|}{-eti verbs } & & \multicolumn{3}{|c|}{-iti verbs } \\
\hline & $\mathrm{U}$ & A & B & & $\mathrm{U}$ & A & B \\
\hline rjaveti & 4.75 & 0 & 0 & blažiti & 4.60 & 1 & 0 \\
\hline medleti & 4.23 & 0 & 0 & jasniti & 4.41 & 0 & 0 \\
\hline hrometi & 4.10 & 0 & 12 & sladiti & 4.32 & 6 & 0 \\
\hline trdeti & 3.83 & 4 & 1 & tesniti & 4.31 & 0 & 0 \\
\hline dreveneti & 3.76 & 2 & 1 & onečistiti & 3.84 & 9 & 0 \\
\hline čvrsteti & 3.72 & 1 & 5 & ožiti & 3.55 & 1 & $\mathbf{0}$ \\
\hline debeleti & 3.23 & 18 & 5 & ledeniti & 3.53 & 1 & 0 \\
\hline nemeti & 3.16 & 3 & 11 & oleseniti & 3.35 & 0 & 0 \\
\hline jekleneti & 3.14 & 0 & 9 & rjaviti & 3.33 & 0 & 1 \\
\hline suroveti & 2.83 & 0 & 21 & besniti & 3.28 & 2 & 3 \\
\hline kosmateti & 2.83 & 1 & 36 & leniti & 3.24 & 0 & 1 \\
\hline kasneti & 2.82 & 46 & 5 & postekleniti & 3.24 & 3 & 1 \\
\hline mrtveti & 2.71 & 44 & 3 & siviti & 3.13 & 0 & 0 \\
\hline bakreneti & 2.68 & 1 & 17 & tujiti & 2.92 & 1 & 1 \\
\hline srepeti & 2.63 & 7 & 7 & izljubiti & 2.90 & 11 & 1 \\
\hline apneneti & 2.48 & 27 & 7 & dreveniti & 2.89 & 1 & 1 \\
\hline pogrdeti & 2.44 & 6 & 24 & glušiti & 2.85 & 2 & 4 \\
\hline plitveti & 2.43 & 2 & 21 & blazniti & 2.84 & 2 & 5 \\
\hline leneti & 2.30 & 37 & 22 & kisliti & 2.82 & 17 & 1 \\
\hline prestareti & 2.26 & 27 & 16 & jekeleniti & 2.76 & 0 & 3 \\
\hline samotneti & 2.25 & 20 & 32 & mrtviti & 2.74 & 7 & 0 \\
\hline ogrbeti & 2.17 & 2 & 29 & slabotniti & 2.50 & 7 & 0 \\
\hline otolsteti & 2.15 & 14 & 8 & drobniti & 2.47 & 25 & 2 \\
\hline kruteti & 2.12 & 1 & 49 & porevniti & 2.41 & 8 & 3 \\
\hline goleti & 2.10 & 7 & 21 & ogrditi & 2.33 & 10 & 3 \\
\hline pobedasteti & 2.01 & 33 & 27 & srepiti & 2.32 & 0 & 2 \\
\hline mrzleti & 1.92 & 38 & 20 & huditi & 2.24 & 23 & 4 \\
\hline žolteti & 1.87 & 15 & 8 & pomnogoteriti & 2.21 & 37 & 0 \\
\hline porevneti & 1.82 & 16 & 31 & grobiti & 2.20 & 0 & 1 \\
\hline globeti & 1.71 & 11 & 17 & bahatiti & 2.05 & 58 & 3 \\
\hline plašeti & 1.50 & 16 & 43 & poočiti & 1.80 & 20 & 2 \\
\hline osmeleti & 1.44 & 1 & 7 & osmeliti & 1.32 & 1 & 1 \\
\hline godneti & 1.43 & 6 & 16 & zanoviti & 1.31 & 16 & 5 \\
\hline
\end{tabular}


cators and on the other for verbs with the indicators "redk.," "star." and "zastar." in the $S S K J$, we see that the majority of the verbs in the latter category receive high frequency ratings (even with an adjustment to allow for the subjects' high ratings just described). These include the "rare" debeleti and jekleneti, the "bookish and rare" ogrobeti, the "archaic" žolteti, and, most surprisingly, given that the definiton of the indicator includes the words "danes je ... mrtva," the "obsolete" globeti. In addition, this evidence seems to suggest that dreveneti should be marked "rare" in the $S S K J$.

The same comparison on Table V (with, as previously, an adjustment) shows a similar picture: high average ratings are given to blažiti and bahatiti (both "rare"), to blazniti and siviti (both "bookish"), and to postekleniti and izljubiti (both "rare" and "bookish"). In addition, this evidence suggests that ožiti and onečistiti should be furnished with indicators in the SSKJ. The results summarized in this and the preceding paragraph provide very strong grounds for suggesting that one of two facts must obtain: either the indicators in the SSKJ (at least for these verbs, but - given their random selection - probably for others) are inaccurate, and require revision; or, at best, that these indicators reflect the language of older generations, not that of the students who took these tests. ${ }^{21}$ These results call, at the very least, for further empirical research into the "rarity," the "archaicness" and the "obsoleteness" of words in the $S S K J .^{22}$

For the second point, we recall that the definition of the kvalifikator "redko" in the SSKJ is, "beseda, ki je sicer v splošni rabi, pa je v razmerju do sinonima precej redka." On Table VIII, verbs with the indicator "redko" are shown in bold type. It can be seen that 58 of the student repondents wrote in single-word synonyms for bahatiti - from a total of 123 students - and the number of students who could think of synonyms for the other "rare" verbs was 38 (mrzleti), 18 (debeleti), and 14 (otolsteti); for the other 12 verbs, less than 10 of the 123 students could think of synonyms. In some instances, they found it easy to express the meaning of the verb - thus, 36 students wrote in a paraphrase for kosmateti - but, overall, very few of the "rare" words did in fact have synonyms which were easily brought to mind. Again, some re-examination of the indicator "redko" is suggested.

\subsection{Awareness of Norm}

It was argued, prior to administering these tests, that question (1) - Ali se po vašem beseda nahaja $\mathrm{v}$ knjižni slovenščini? - might be informative in quite a different way; specifically, that answers to this question should be assumed to reflect an awareness of the norm. If some subjects rated verbs higher on this scale than did other subjects, they might be said to show a greater self-assuredness in their judgments as to which verbs belong more, and which belong less, to Standard Literary Slovene. This was not assumed to mean that their judgments would necessarily be more reliable (although this might also be true); but it would indicate, at least, that they believed that their judgments were more reliable. It was therefore hypothesized that various extralinguistic factors might affect the responses to question (1)

\footnotetext{
${ }^{21}$ For average ages, see footnote 13.

${ }^{22}$ Re-evaluation of one other subset of indicators (the 'expressive' ones) for the SSKJ is proposed and described in Žele 1993.
} 
- factors having to do with the amount to which individual speakers had been exposed to Standard Literary Slovene during their lives to date, which exposure would influence their self-confidence.

Of the personal details collected from respondents, the following were used for analysis: (1) sex, (2) current level of education, (3) being in a "language-oriented" educational stream or not, (4-5) recent scholastic level of attainment, (6-8) place of longest residence of self and parents, (9-10) education of parents, and (11-12) socio-economic status of parents. For (2) data from secondary school students were tabulated separately from those from university students. For (3) subjects were divided into groups according to their specialization: those studying at the Upravno-administrativna šola, the Gimnazija, the Filozofska fakulteta and the Pedagoška akademija were classified as language-oriented, and those in the others as non-language, i.e., as technically, oriented. ${ }^{23}$ For (4) and (5) subjects reported their most recent average grades, respectively, in language classes and in all subjects; these were divided into "lower" and "higher" grades. For (6) through (8) subjects listed their own and their parents' places of residence during their lives; the place where each spent most of their linguistically formative years, i.e., from age 1.6 through late teens, was taken as indicative of dialect background, whereby Ljubljana, Upper and Lower Carniola were somewhat arbitrarily counted as "central" and all other areas within Slovenia as "peripheral." ${ }^{4}$ For (9) and (10) they reported whether their parents had finished primary, secondary, or post-secondary school; figures for the first and third of these subsets were contrasted. And finally for (11) and (12) subjects reported the occupation of each parent; these were ranked according to the Pineo Scale (see Pineo, Porter and McRoberts 1977) as interpreted for occupational categories in Slovenia; those in the upper half of the scale (18-10) were contrasted with those in the lower half (9-1).

On each of Tables IX through XIII mean scores for responses to question (1) are displayed, for each of -eti and -iti, and for all verbs except the six made-up words in each instance (which were omitted from this analysis since they may not belong to the norm). In the third row of each section of the tables is an expression of the difference in responses from the two subsets of respondents, viz., the difference between the two means, expressed as a percentage of the lower mean. Thus, in Table IX, the third row of the first section reads "university : high school ... [eti] $8.1 \ldots$ [iti] 4.8"; this is to be read as "for -eti verbs, the mean for those attending university was 8.1 higher than the mean for those attending high school; for -iti verbs, the former was 4.8 higher than the latter." It will be noted that in only one instance (the "total grades" figures) do the indications for -eti verbs on the one hand, and for -iti verbs on the other, disagree; this general agreement shows, surely, the strength of the conclusions listed below. It will also be noted that the indications for -iti verbs are, in many but not all cases, much higher than those for -eti verbs. This result requires further study; is it linked to the hypothesized and - hopefully demonstrated higher productivity of -iti?

Under the general heading "educational and intellectual development" we con-

${ }^{23}$ Full details of educational institutions in note 2.

${ }^{24}$ Subjects who reported their own, their mothers' or their fathers' formative places of residence as being outside Slovenia were omitted from the relevant calculations. 
sider the following results (see Table IX). Students at university had higher mean scores than students in high schools; students with "language-oriented" specialization, here labelled "humanities," had higher mean scores than "technical" students. Those who had higher grades in the previous year tended to have higher scores than those who had lower ones. Of these factors, it is striking that the most influential appears to be the orientation toward or away from the use of language. Three parameters can be examined under the heading "dialect influence," as on Table X. In all three instances, residence in central Slovenia for the subjects themselves and for their parents correlates with high assessments, as compared with residence in more peripheral areas of the country. Interestingly, the places where the subjects' parents grew up is of more importance than the places where the subjects themselves did so; and, in addition, the mother's place of residence is more influential than that of the father.

Third, we consider the education of the parents (Table XI). Subjects whose parents had graduated from higher education had higher scores than subjects whose parents had only had primary education. Here again, mothers figure more prominently than fathers. Fourth, let us examine Table XII, which reports scores according to the socio-economic status of the parents. Subjects whose parents had a higher socio-economic status had higher scores than subjects with parents with lower status; in this instance, fathers figure more prominently than mothers.

Finally, let us have a look at sex differences, as displayed in Table XIII: it is clear that females had higher mean scores than did males.

Table IX. Extralinguistic Variables: Educational and Intellectual Level

\begin{tabular}{lcc}
\hline & - eti & $-i t i$ \\
\cline { 2 - 3 } attending university & 3.06 & 2.83 \\
attending high school & 2.83 & 2.70 \\
\hline university : high school \% & +8.1 & +4.8 \\
specializing in humanities & 3.21 & 2.95 \\
specializing in technical subjects & 2.71 & 2.58 \\
\hline humanities : technical \% & +18.5 & +14.3 \\
& & \\
high language grades & 2.91 & 2.85 \\
low language grades & 2.87 & 2.65 \\
\hline higher : lower \% & +1.4 & +7.5 \\
high total grades & & \\
low total grades & 2.89 & 2.85 \\
\hline higher : lower \% & 2.89 & 2.66 \\
\hline
\end{tabular}


Table X. Extralinguistic Variables: Place of Longest Formative Residence

\begin{tabular}{lcr}
\hline & $-e t i$ & $-i t i$ \\
\cline { 2 - 3 } & & 3.00 \\
self: resident central Slovenia & 2.91 & 2.85 \\
self: resident elsewhere in Slovenia & +3.1 & 2.61 \\
\hline central : elsewhere \% & & +9.2 \\
& 3.09 & 2.91 \\
father from central Slovenia & 2.90 & 2.62 \\
father from elsewhere in Slovenia & +6.6 & +10.7 \\
\hline central : elsewhere \% & & \\
& 3.12 & 3.00 \\
mother from central Slovenia & 2.88 & 2.61 \\
mother from elsewhere in Slovenia & +8.3 & +14.9 \\
\hline central : elsewhere \% & &
\end{tabular}

Table XI. Extralinguistic Variables. Parents' Education

\begin{tabular}{lcc}
\hline & $-e t i$ & $-i t i$ \\
\cline { 2 - 3 } & 3.02 & 2.82 \\
father higher education & 3.01 & 2.74 \\
father lower education & +0.3 & +2.9 \\
\hline higher : lower \% & & \\
mother higher education & 3.06 & 2.94 \\
mother lower education & 2.81 & 2.63 \\
\hline higher : lower \% & +8.9 & +11.8 \\
\hline
\end{tabular}

Table XII. Extralinguistic Variables: Parents' Socio-Economic Status

\begin{tabular}{lcr}
\hline & $-e t i$ & $-i t i$ \\
\cline { 2 - 3 } & & \\
father higher socio-economic status & 3.04 & 2.80 \\
father lower socio-economic status & 2.81 & 2.62 \\
\hline higher : lower \% & +8.2 & +6.9 \\
& & \\
mother higher socio-economic status & 3.00 & 2.70 \\
mother lower socio-economic status & 2.84 & 2.59 \\
\hline higher : lower \% & +5.6 & +4.2 \\
\hline
\end{tabular}


Table XIII. Extralinguistic Variables: Sex of Respondents

\begin{tabular}{lcr}
\hline & $-e t i$ & $-i t i$ \\
\cline { 2 - 3 } females & 2.93 & 2.75 \\
males & 2.69 & 2.43 \\
\hline females : males \% & +8.9 & +13.1 \\
\hline
\end{tabular}

To summarize: a higher awareness of the norm has been demonstrated among certain specific subsets of respondents in this study; namely, a heightened awareness was reported by those at a more advanced intellectual or educational level; by those who had a personal and family background based in central, rather than peripheral, dialects of Slovene; by those whose parents were better educated and of a higher socio-economic status; and by those who used, or were being trained to use, language more rather than less in their occupations. In addition, females reported a more heightened awareness of the norm than males. Most of these conclusions are, indeed, what one may have expected: a greater awareness of the norms of Standard Literary Slovene may be predicted among those who are brought up by and among central dialect-speakers, given that the standard language is closer to these varieties. It may be predicted among those who are better educated, and among those who are being trained not in technical subjects but in the humanities. It may be predicted among those with better-educated and more socio-economically advantaged parents. It may also, given what has been shown for sociolinguistic differences between the sexes, be predicted for females rather than males. ${ }^{25}$ It is nevertheless of interest to be able to demonstrate that these predictions hold; and some of the details - the greater role of the mother's education on the one hand, and of the father's socio-economic status on the other - are striking. These results, when replicated, may have implications for those who are involved in teaching Standard Slovene in Slovene schools, who may thus with justification take extra care in the teaching of the language to schoolchildren in particular subgroups and with particular backgrounds; for, although an awareness of the standard norm may not reflect ability to use that norm, it will surely, at least, be reflected in individual speakers' self-confidence.

\section{Suggestions and Conclusions}

\subsection{Suggestions}

It cannot be over-emphasized that this was a first hesitant step in empirical research into derivational productivity in Slovene. Apart from further replication of the tests outlines above, and in particular of the tests resulting in $\mathbf{p}$-ratings and $\mathbf{u}$ ratings, there are many other aspects of this problem to be explored. Among them are the following:

Derivations are not all of the same kind; especially, some are, to use the words of Dressler (1986), more and some are less morphosemantically transparent. ${ }^{26}$

\footnotetext{
${ }^{25}$ On the tendency for adult females (especially those in certain socio-economic groups) to prefer more standard forms, see Chambers 1995.

${ }^{26}$ This concept has much in common with that of "motivatedness," see, e.g., Lopatin and Uluxanov (1966) and Ermakova and Zemskaja (1991) on motivirannost'; see Armstrong (1978) and
} 
Derivations which are more so may, I suggest, be more amenable to tests of the kind described here, ${ }^{27}$ the denominal/deadjectival suffixes -oba, -ost and -stvo may for instance provide rewarding material for such tests. Replication of these tests with the same or similar cues should be performed, but with attention to two aspects of the problem which I was not able, for feasibility reasons, to incorporate. First, it would be informative to contrast derivatives which involve affixation on a simple stem with those involving more complex affixation. Among the cues for the 1993 tests, for instance, the majority consisted of the $-e$ - or the $-i$ - suffix being added to simple stems; but in several the suffix was added to already-suffixed stems - several with -en-, e.g., bakr-en-e-ti, stekl-en-i-ti; a few with phonologically more complex components, e.g., kos-mat-e-ti, mnogo-ter-i-ti; two, even, which already had two suf-

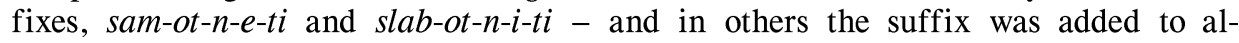
ready-prefixed stems (pre-star-e-ti, o-ne-čist-i-ti). One cue, indeed, has a combination of these features - po-bed-ast-e-ti. Inspection of Tables IV and V does not detect any pattern which sets the results for these verbs off from the results for more simple derivations. Attention to this factor could - and, for those who may wish to hypothesize that derivation involves processes with greater or lesser "depth" - should be the basis for further testing.

Second, there was no opportunity in the experiments reported here to incorporate variables representing the role of semantics within the scope of operation of individual DPs. As mentioned briefly above (2.1), most of the derivations were semantically transparent (thus, the relationship between rjaveti "to become brown" and rjav "brown"), but a few were semantically more opaque (e.g., the relationship is not so obvious between dreveneti "to stiffen" and dreven "made of wood," and that between izljubiti "to adore" and ljub "dear" is even more tenuous). An experiment should be devised with cues ranging from the perfectly transparent to the extremely opaque, to see if this factor is involved in productivity. In addition, a different kind of test - one in which subjects would have to interpret the meanings of "made-up" words - would clarify this aspect of the question.

\subsection{Conclusions}

As far as productivity is concerned, there are three main conclusions. First, it is very clear that, for these DPs, productivity is a "cline," but in two quite distinct meanings of the term (3.1). Second, there is an enormous difference between type frequency and productivity (3.2). Third, the formula $(\mathbf{p}-\mathbf{u}) \div \mathbf{u}$, as described, appears to provide a measure of the relative productivity of different DPs, and specifically shows that $-i t i$ is more productive than -eti (3.3). The applicability of this formula should be checked by tests with much more extensive lists of cues, for it is, to the best of my knowledge, something new. And the results of the investigation into "blocking" (3.4) were suggestive, but inconclusive.

In addition, the kvalifikatorji in the SSKJ deserve re-examination and, if possible, empirical justification (4.1); and it has been shown possible to determine which speakers of Slovene have a greater, and which ones have a lesser, awareness of the standard norm (4.2).

Górska (1983) who also discuss relative productivity in terms of semantic relationships among morphemes.

${ }^{27}$ This was pointed out to me by Wolfgang Dressler, personal communication, 1993. 


\section{Appendix I: Cues for 1993 Tests}

Underlined verbs are made-up derivations.

\section{Inchoative}

apnen 'calceous' apneneti; bakren 'made of copper' bakreneti; bedast 'foolish' pobedasteti; čvrst 'firm' čvrsteti; debel 'fat' debeleti; dreven 'made of wood' dreveneti; globok 'deep' globeti; goden 'ripe' godneti; gol 'naked' goleti; grd 'ugly' pogrdeti; grob 'rough' ogrobeti; hrom 'lame' hrometi; jeklen 'made of steel' jekleneti; kasen 'late' kasneti; kosmat 'hairy' kosmateti; krut 'cruel' kruteti; len 'idle' leneti; medel 'flabby' medleti; mrtev 'dead' mrtveti; mrzel 'cold' mrzleti; nem 'dumb' nemeti; plah 'timid' plašeti; plitev 'shallow' plitveti; pre-star 'too old' prestareti; reven 'poor' porevneti; rjav 'brown' rjaveti; samoten 'lonely' samotneti; smel 'bold' osmeleti; srep 'staring' srepeti; surov 'crude' suroveti; tolst 'fat' otolsteti; trd 'hard' trdeti; žolt 'yellow' žolteti

\section{Factitive}

bahat 'proud' bahatiti; besen 'angry' besniti; blag 'gentle' blažiti; blazen 'insane' blazniti; dreven dreveniti; droben 'tiny' drobniti; gluh 'deaf' glušiti; grd ogrditi; grob grobiti; hud 'bad' huditi; ljub 'dear' izljubiti; jasen 'clear' jasniti; jeklen jekleniti; $k i$ sel 'sour' kisliti; leden 'icy' ledeniti; len leniti; lesen 'made of wood' oleseniti; mnogoter 'manifold' pomnogoteriti; mrtev mrtviti; ne-čist 'unclean' onečistiti; nov 'new' zanoviti; očit 'obvious' poočititi; ozek 'narrow' ožiti; reven porevniti; rjav rjaviti; siv 'grey' siviti; slaboten 'feeble' slabotniti; sladek 'sweet' sladiti; smel osmeliti; srep srepiti; steklen 'made of glass' postekleniti; tesen 'tight' tesniti; tuj 'strange' tujiti

\section{Appendix II: Cues for 1994 Tests}

Glosses are provided only for adjectives not used for derivatives for the 1993 test.

\section{Inchoative}

apnen apneneti; bakren bakreneti; čvrst čvrsteti; dreven dreveneti; fanatičen 'fanatical' fanatičneti; gibčen 'supple' gibčneti; gotov 'complete' dogotoveti; hrom hrometi; jeklen jeklenet $i$; kasen kasneti; klavrn 'low-spirited' klavrneti; kosmat kosmateti; krut kruteti; len leneti; ljubezniv 'kind' ljubezniveti; mlačen 'lukewarm' mlačneti; močan 'strong' omočneti; mrtev mrtveti; nem nemeti; nemočen 'feeble' onemočneti; plah plašeti; rjav rjaveti; rožnat 'pink' rožnateti; samoten samotneti; slaboten slabotneti; smel osmeleti; srep srepeti; surov suroveti; štorast 'clumsy' $\underline{\text { storasteti; }}$ žolt žolteti

\section{Factitive}

besen besniti; blag blažiti; blaten 'muddy' blatniti; blazen blazniti; dreven dreveniti; droben drobniti; gluh glušiti; grd ogrditi; grob grobiti; jeklen jekleniti; kisel kisliti; leden ledeniti; len leniti; mršav 'lean' mršaviti; mrtev mrtviti; ne-čist onečistiti; ne-strupen 'not poisonous' onestrupeniti; nov zanoviti; ozek ožiti; ploden 'fertile' plodniti; popularen 'popular' popularniti; reven porevniti; rjav rjaviti; rožnat 'pink' rožnatiti; slaboten slabotniti; srep srepiti; strupen 'poisonous' ostrupeniti; tesen tesniti; živčen 'nervous' živčniti; žolt ožoltiti 


\section{Bibliography}

Anshen, Frank, and Mark Aronoff. 1981. "Morphological productivity and phonological transparency," Canadian Journal of Linguistics 16: 63-72.

Armstrong, Daniel. 1978. "Toward a comparative semantic analysis of suffixal word formation in Slavic," 45-81 in H. Birnbaum, ed., American Contributions to the Eighth International Congress of Slavists. Columbus, OH: Slavica.

Aronoff, Mark. 1976. Word Formation in Generative Grammar. Cambridge MA: MIT Press.

- - and R. Schvaneveldt. 1978. "Testing morphological productivity," Annals of the New York Academy of Sciences 318: 106-114.

Baayen, Harald. 1992. "Quantitative aspects of morphological productivity," 104-49 in Booi and Marle 1992.

- - and Rochelle Lieber. 1991. "Productivity and English derivation: A corpus based study," Linguistics 29: 801-43.

Bauer, Laurie. 1988. Introducing Linguistic Morphology. Edinburgh: Edinburgh University Press.

Besedišče 1987 = Milena Hajnšek-Holz, Marjeta Humar and Franc Jakopin, eds. Besedišče slovenskega jezika I-II. Ljubljana: Znanstvenoraziskovalni center SAZU. Inštitut za slovenski jezik Frana Ramovša.

Booi, Geert, and Jaap van Marle. 1988. Yearbook of Morphology. Dordrecht: Kluwer.

- - and - -. 1992. Yearbook of Morphology 1991. Dordrecht: Kluwer.

Browne, Wayles. 1981. "Slavic - $b a$ and English *slil: Two persistent constraints," Folia Slavica 4/1-3: 219-226.

Chambers, Jack. 1995. Sociolinguistic Theory: Language Variation and its Social Implications. Oxford: Blackwell.

Corbin, Danielle. 1987. Morphologie dérivationelle et structuration de la lexique I-II. Tübingen: Niemeyer.

Derwing, Bruce L. 1976. "Morpheme recognition and the learning of rules for derivational morphology," Canadian Journal of Linguistics 21/1: 38-66.

Di Sciullio, A.-M., and E. Williams. 1987. On the Definition of Word. Cambridge MA: MIT Press.

Dressler, Wolfgang. 1987. "Explanation in natural morphology, illustrated with comparative and agent-noun formation," Linguistics 24: 519-548.

Gjurin, Velemir. 1985. "Priponsko obrazilo $-a \check{s}$ v slovenččini," Slavistična revija 33: 195-222.

Górska, Elzbieta. 1983. "The methods of establishing the productivity of word formation rules," Papers and Studies in Contrastive Linguistics 16: 91-98.

Greenberg, Sidney, and Randolph Quirk. 1970. Elicitation Experiments in English. Linguistic Studies in Use and Attitude. London: Longmans, 1970.

Lieber, Rochelle. 1992. Deconstructing Morphology. Word Formation in Syntactic Theory. Chicago: University of Chicago Press. 
Lopatin, V. V., and Uluxanov, I. S. 1966. "Glagoli na -et' v sovremennom russkom jazyke (O produktivnosti i reguljarnosti slovoobrazovatel'nogo tipa)," 127-41 in Zemskaja, E. A., and Šmeleva, D. N. 1966. Razvitie slovoobrazovanija sovremennogo russkogo jazyka. Moscow: Nauka.

Mader, Elfriede. 1981. Rückläufiges Wörterbuch des Slowenischen. Klagenfurt: Klagenfurter Sprachwissenschaftliche Gesellschaft.

Marle, Jaap van. 1988. "On the role of semantics in productivity change," 139-54 in Booi and Marle 1988.

Pineo, Peter C., John Porter and Hugh A. McRoberts. 1977. "The 1971 census and the socioeconomic classification of occupations," Canadian Review of Sociology and Anthropology 14/1: 91-102.

Pleteršnik, Maks. 1894. Slovensko-nemški slovar I-II. Ljubljana: Knezoškofijstvo.

Priestly, Tom. 1987. "Slovene verb productivity,” Slovene Studies 9/1-2: 195-203.

Rainer, Franz. 1988. "Towards a theory of blocking: The case of Italian and German quality nouns," 155-85 in Booi and Marle 1988.

Schultinck, Henk. 1961. "Produktiviteit als morfologisch fenomeen," Forum der Letteren 2: 110-25.

SSKJ = Slovar slovenskega knjižnega jezika I-V. Ljubljana: Slovenska akademija znanosti in umetnosti.

Toporišič, Jože. 1984. Slovenska slovnica. Maribor: Obzorja.

Vakareliyska, Cynthia. 1994. "Na-drop in Bulgarian," Journal of Slavic Linguistics 2/1: 121-150.

Vidovič-Muha, Ada. 1981. "Pomenske skupine nekakovostnih izpeljanih pridevnikov." Slavistična revija 29: 19-42.

- -. 1983. "Zloženke s pomenom lastnosti delov organizma," Slavistična revija 31: 359-374.

Žele, Andreja. 1993. "Ekspresivne oziroma čustvene oznake v slovarstvu," Slavistična revija 41: 529-534.

Prispelo aprila 1998, sprejeto junija 1998

Received April 1998, accepted June 1998

\section{O produktivnosti izpeljave $\mathrm{v}$ slovenščini s pripombami o besedni pogostnosti in zavedanju norme}

Poglavitni cilj pričujoče raziskave je ugotavljanje možnosti za merjenje produktivnosti besedotvornih vzorcev oz. besedotvornih postopkov, kar očitno še ni bilo izvedeno za noben jezik. Gradivo za študijo predstavljata dva nasprotujoča si izpridevniška besedotvorna vzorca: »inhoativno« obrazilo - eti in »faktitivno« obrazilo -iti, kot npr. rjav $\rightarrow$ rjaveti 'postajati rjav' proti rjaviti 'delati rjavo'. Analiza je bila izpeljana na osnovi psihološkega testiranja, ki je bilo izvedeno v Ljubljani v letih 1993-94. L. 1993 je bilo testirano 186 dijakov in 180 dodiplomskih študentov. V nadaljevanju 1. 
1994 je bilo testiranje omejeno na tri skupine univerzitetnih študentov, ki jih je sestavljalo skupaj 116 oseb. Zastavljena so bila štiri vprašanja: (1) Ali se po vašem beseda nahaja v knjižni slovenščini? (2) Ali vi to besedo kdaj uporabljate? (3) Ali je ta beseda po vašem možna in razumljiva? in (4) Kako pogosto sami uporabljate to besedo? Testirani so izbirali med petimi možnostmi, ki so bile rangirane po Likertovi lestvici, in podatki so bili nato statistično obdelani. Kar zadeva produktivnost, se je izkazalo - vsaj za ta dva besedotvorna vzorca -, da jo lahko opišemo kot poševni potek, vendar $\mathrm{v}$ dveh različnih pomenih tega izraza. Prvi pomen je samoumeven: en postopek je lahko bolj produktiven kot drugi. Drugi pomen je ta, da t.i. "produktivna moč« lahko variira. Če vzamemo dva primera iz srednjih odgovorov na vprašanje (3), je razvidno, da je bila beseda godneti povprečno ocenjena kot skrajno »možna in razumljiva«, medtem ko je bila na drugem koncu lestvice beseda plašeti ocenjena kot skorajda nemogoča. Med tema dvema skrajnostma se vrstijo vse druge vprašane besede.

Drugič, obstaja velika razlika med vrstno pogostnostjo in produktivnostjo. $\mathrm{Na}$ to pogosto kažejo precejšne razlike med odgovori v zvezi z isto vprašano besedo, na vprašanje (4) in druga vprašanja. Tretjič, zdi se, da nam merilo za relativno produktivnost raličnih vzorcev daje posebna formula. Ta formula je $(\mathbf{p}-\mathbf{u}) \div \mathbf{u}$, pri čemer je p srednja vrednost za odgovore na vprašanje (3), u pa sredina odgovorov na vprašanje (2). Formula izraža količino, za katero odgovori na vprašanje (3) (povprečno) presegajo odgovore na vprašanje (2). Ta razlika je drugačna za dejanske besede in za izmišljene besede. Podatki iz raziskave $\mathrm{v}$ Ljubljani 1. 1993, z uporabo omenjene formule, kažejo, da je - kot je bilo pričakovano - obrazilo -iti bolj produktivno kot -eti. Za preverjenje tega rezultata je bilo izvedeno drugo testiranje 1. 1994 in rezultati so bili pritrdilni. Kljub temu so ti rezultati v več pogledih le pripravljalne narave. Priporočamo obnovitev in razširitev testiranja.

Poleg tega, je bil kot podpostopek testiranja $v$ zvezi $z$ vprašanjem (2) raziskan pojav »blokiranja«. Čeprav rezultati niso dokončni, so zgovorni, in test lahko prilagodimo za raziskavo tega pojava.

Prišli smo še do dveh drugih zaključkov, ki pa nista $\mathrm{v}$ zvezi $\mathrm{z}$ besedotvorno produktivnostjo. Nekateri kvalifikatorji, ki jih navaja $S S K J$ za glagole v testih, se zdijo na osnovi srednjih odgovorov na vprašanje (4) nepravilni. Ta rezultat morda velja le za subjekte testiranja, ki so večinoma stari 16 do 24 let. Menimo pa, da bi se kvalifikatorje izplačalo ponovno oceniti in, če je mogoče, tudi empirično utemeljiti. Podatki o subjektih, ki so opravili teste, so bili analizirani glede na odgovore na vprašanje (1). Izsledki te analize kažejo, da je zavedanje slovenske knjižne norme večje, če ima subjekt višjo intelektualno in/ali izobrazbeno stopnjo, če je iz osrednjih slovenskih narečnih skupin, če ima starše z višjo izobrazbo in/ali višjim družbeno-gospodarskim položajem in če je bil izšolan za večjo rabo jezika pri delu. Poleg tega se ženske bolj zavedajo norme kot moški. Ti rezultati imajo pomen za šolske učitelje slovenščine. 


\section{On Derivational Productivity in Slovene with Notes on Lexical Frequency and Awareness of the Norm}

The major aim of the study reported here was to discover a way of measuring the productivity of derivative patterns or processes, a task which appears never to have been accomplished for any language before. As specific material for the study, two contrasting deadjectival verbal derivative patterns were chosen: the 'inchoative' -eti and the 'factitive' -iti, as occurring in, e.g., rjav 'brown', rjaveti 'to become brown', rjaviti 'to make (someone or something) brown.' The method involved psycholinguistic tests, administered in Ljubljana in 1993-94. The subjects for the tests in 1993 were 186 secondary and 180 post-secondary students. For the 1994 follow-up study the tests were limited to three groups of university respondents, totalling 116 in all. Cues comprised four questions: (1) Ali se po vašem beseda nahaja v knjižni slovenščini? (2) Ali vi to besedo kdaj uporabljate? (3) Ali je ta beseda po vašem možna in razumljiva? and (4) Kako pogosto sami uporabljate to besedo? Subjects selected responses on five-point Likert scales; the data were analyzed statistically. As far as productivity is concerned, there are three conclusions. First, it is clear that, at least for these derivative patterns, productivity is a "cline," but in two quite distinct meanings of the term. First and most obviously, one process may be synchronically more productive than another. Second, what may be called the productive strength of any one process also varies. To take just two examples from the mean responses to question (3), we see that the cue godneti was assessed, on average, as extremely "possible and understandable," while at the other end of the scale the cue plašeti was assessed, on average, as well nigh impossible and incomprehensible; the remaining cues are strung out along the cline in between the two.

Second, there is an enormous difference between type frequency and productivity; this is shown specifically by the often very significant differences between answers, for the same cue, to question (4) and the other questions. Third, one particular formula appears to provide a measure of the relative productivity of different patterns. This formula is expressed as $(\mathbf{p}-\mathbf{u}) \div \mathbf{u}$, where $\mathbf{p}$ is the mean for responses to question (3) and $\mathbf{u}$ is the mean for responses to question (2). The formula expresses the amount by which (on average) the responses to Question 3 exceed the responses to Question 2; and this disparity, in turn, is significantly different for real words as compared with made-up words. The data from the experiments in Ljubljana in 1993 showed, using this formula in these applications, that - as hypothesized $--i t i$ is more productive than -eti. To test this finding, a second set of tests were administered in 1994, with confirmatory results. There are however several respects in which this finding must be considered preliminary; replication and extension of the tests is urged.

In addition, the phenomenon known as 'blocking' was investigated with one sub-routine to tests involving question (2). The results, though inconclusive, are suggestive, and this test may be adapted for further investigation of this phenomenon.

Incidentally, two other conclusions, having nothing to do with derivational productivity, were reached. Several of the kvalifikatorji that are provided in the SSKJ for verbs used in the tests appear, on the evidence of mean responses to question (4), to be incorrect; this finding may only apply to the subjects in the tests, who were mostly aged between 16 and 24; but it is suggested that the kvalifikatorji de- 
serve re-examination and, if possible, empirical justification. Finally, information collected about the subjects who did the tests was analyzed with respect to answers to question (1). A higher awareness of the norm of Standard Slovene was reported by those at a more advanced intellectual or educational level; by those who had a personal and family background based in central, rather than peripheral, dialects of Slovene; by those whose parents were better educated and of a higher socio-economic status; and by those who used, or were being trained to use, language more rather than less in their occupations. In addition, females reported a more heightened awareness of the norm than males. This has implications for teachers of the Slovene language in schools. 